\title{
CHRONOLOGY OF RANK'S LIFE
}

\author{
(1884-1939)
}

1884 Born in Vienna, April 22

1905 Sends Freud a manuscript entitled The Artist, using the word artist in as comprehensive sense as Freud had used the word sexuality

1906 Accepts Freud's offer to be secretary of the fledgling Vienna Psychoanalytical Society, the first paid position in the movement; is virtually adopted by Freud as a "foster son"; and is asked by Freud to devote himself to the nonmedical side of psychoanalysis

1907 Publishes The Artist, the first psychoanalytic work not written by Freud

1909 Publishes The Myth of the Birth of the Hero, with a section on the "family romance" contributed by Freud

1911 Helps Freud edit and revise the third edition of The Interpretation of Dreams

1911 Publishes The Lohengrin Saga, for which he later receives a Ph.D. from the University of Vienna, the first dissertation ever written on a psychoanalytic theme

1912 Publishes The Incest Theme in Literature and Legend: Fundamentals of a Psychology of Literary Creation, a 685-page study of the Oedipus complex throughout world literature

1912 Becomes the youngest ringholder of the secret Committee-Abraham, Ferenczi, Sachs, Jones (and later, Eitingon)-formed by Freud to defend the cause

1912 Co-founds Imago and Internationale Zeitschrift für ärztliche Psychoanalyse, the two leading journals of the cause

1913 Publishes, with Sachs, The Significance of Psychoanalysis for the Mental Sciences

1914 Contributes two chapters, on literature and myth, to the fourth edition of The Interpretation of Dreams, his name now appearing (until 1929) below Freud's on the title page

1914 Publishes The Double, a study of the core problems of human existence as expressed in cinema and literature: identity, guilt, narcissism, the fear of death, the soul, and the desire for immortality

1916-18 Serves as editor-in-chief of the Krakauer Zeitung, the official army newspaper in Poland

1918 Marries Tola Minzer, 23, in Poland

1919 Returns to Vienna to edit Imago and Internationale Zeitschrift and is asked by Freud to become director of the Verlag, the newly created international psychoanalytic publishing house, and vice-president of the Vienna Psychoanalytical Society

1919 Begins full-time practice as a lay analyst and conducts training analyses for visiting Americans

1919 Helene, his only child, is born 
1922-23 Drafts with Ferenczi, now his best friend, The Development of Psychoanalysis, which advocates the curative effect of emotional experience [Erlebnis] over intellectual understanding [Einsicht]

1923 Is informed, immediately after diagnosis, of Freud's life-threatening cancer of the jaw

1924 Publishes, with Ferenzci, The Development of Psychoanalysis, criticizing the "fanaticism for interpreting" among analysts: "the actual analytic task," they say, "was neglected"

1924 Publishes The Trauma of Birth, claiming that the "ambivalent" preOedipal relationship between mother and child is the heart of transference, thereby relegating fear and love of the Oedipal father to a secondary place

1924 Sails for the United States in April and lectures on his pre-Oedipal theory before the American Psychoanalytic Association and other audiences

1924 From the United States, in an August letter, denies Freud's charge that he has "excluded the father; naturally that is not the case and absolutely cannot be, it would be nonsense. I have only attempted to give him the correct place"

1925 Confesses in January to an Oedipal neurosis, "occasioned by the dangerous illness of the Professor," after a soul-baring Erlebnis therapy in December 1924 with Freud, who forgives him

1925 At a seminar for the New York Psychoanalytic Society, insists, "The only real new viewpoint in [my] contribution [is] the concept of the preOedipus level"

1926 Recants his Oedipal neurosis, resigns from his editorial and administrative positions, and moves to Paris in April to start a new practice, severing all ties with medical psychoanalysis and the secret Committee

1926 Delivers a series of lectures before the New York School of Social Work, based on Volume 1 of his forthcoming work, Genetische Psychologie (1927), whose opening sentence reads: "This book is a direct continuation ... of my new vision in psychoanalytic theory and therapy"

1926 In his New York lectures, accuses Freud of repressing the role of the castrating pre-Oedipal mother: "The 'bad mother' he has never seen, but only the later displacement of her to the father, who therefore plays such an omnipotent part in his theory. ... The 'strict mother' thus forms the real nucleus of the super-ego"

1927 Delivers a series of lectures before the University of Pennsylvania School of Social Work, based on Volume 2 of his forthcoming work, Genetische Psychologie (1928)

1927 In a lecture at the University of Pennsylvania, announces that he is no longer "going back" to the pre-Oedipal mother: many neurotics belong to the "creative type" but "have failed in the formation and development of their own personality"; they are, in essence, failed artists

1927 In other University of Pennsylvania lectures, defines love in terms of the I-Thou relationship: "The love of the Thou ... places a value on one's own I. Love abolishes egoism, it merges the self in the other to find it again enriched in one's own I. ... One can really only love the one who 


\section{CHRONOLOGY OF RANK'S LIFE XV}

accepts our own self as it is, indeed will not have it otherwise than it is, and whose self we accept as it is"

In the same lecture, defines guilt as a "special emotion," lying on "the boundary line . . . between the severing and uniting feelings; [therefore,] it is also the most important representative of the relation between inner and outer, I and Thou, the Self and the World"

1929-31 Delivers another series of lectures at the University of Pennsylvania based on two books published in English as Will Therapy and Truth and Reality, claiming that "the real 1 , or self with its own power, the will, is left out" of psychoanalysis, but stressing repeatedly that "will and guilt are the two complementary sides of one and the same phenomenon"which he calls the will-guilt problem

1929-31 Reframing Freud's "economic" metaphor of drive, asserts in Will Therapy that the neurotic (or artiste manqué) "bribes" life itself-for which we all have to "pay" with death: because of extreme guilt and anxiety, the neurotic hurls a Big No at the consciousness of living, refusing the loan, life, in order to escape payment of the debt, death

1930 Publishes Seelenglaube und Psychologie (translated, in 1950, as Psychology and the Soul), drawing on Bohr's "theory of complementarity" and Heisenberg's "uncertainty principle" to demonstrate that quantum physics has proved that the human being "simply lies beyond lawfulness, and cannot be fully comprehended or explained by the causality either of natural or social science"-or "the cause" of psychoanalysis

1930 In a Washington lecture, attended by a large international audience, says that while he has stopped calling himself a psychoanalyst, "I am no longer trying to prove that Freud was wrong and I am right. . . . It is not a question of whose interpretation is correct-because there is no such thing as the interpretation or only one psychological truth"

1930 Removed by the American Psychoanalytic Association from its list of honorary members, immediately after the Washington lecture, on a motion by APA President A. A. Brill, seconded by Vice-President Harry Stack Sullivan: reanalysis of his analysands by Freudians is required for them to retain membership in the APA

1932 Publishes Art and Artist, showing that only the "human creative impulse" can constructively harmonize "the fundamental dualism" of life and death, a dualism Rank explores along many lines: for example, the wish for-and fear of-separation, the wish for-and fear of-union, the oscillation between life Angst and death Angst, independence and dependence, I and Thou, and, most importantly, the "will-guilt problem"

1932 Publishes Modern Education, concluding that "psychoanalysis is as conservative as it appeared revolutionary; for its founder is a rebellious son who defends paternal authority, a revolutionary who, from fear of his own rebellious son-ego, took refuge in the security of the father role"

1935 Moves from Paris to New York and continues practicing psychotherapy and lecturing in the United States

1936 Meets Carl Rogers and influences him to abandon Freudian technique for "client-centered" and "relationship" therapy 


\section{XVi CHRONOLOGY OF RANK'S LIFE}

1937-39 Drafts Beyond Psychology (published posthumously in 1941), advocating a "psychology of difference" one step beyond Freud's "psychology of likeness"

1939 Divorces Tola Rank and marries Estelle Buel, his secretary, in July

1939 Dies in New York from reaction to injection of a sulfa (antibacterial) drug, on October 31-one month after Freud's death in London, from injection of morphine by his personal physician, on September 23 